\title{
Identification and ranking of compensation strategies for oil distribution companies
}

\author{
Hasan Boudlaie \\ Department of Social and Behavioral Sciences, Kish International Campus, University \\ of Tehran, Tehran, Iran \\ hasanboudlaie@ut.ac.ir
}

Behrouz Keshavarz Nik

M.A. in Executive Management, Kish International Campus, University of Tehran, Tehran, Iran

Behrooz.nik85@gmail.com

\author{
Mohammadhosein Kenarroodi \\ $\mathrm{PhD}$ candidate, Department of Social and Behavioral Sciences, Kish International \\ Campus, University of Tehran, Tehran, Iran \\ mohamad.kenaroodi@ut.ac.ir
}

\begin{abstract}
The purpose of the current study was to identify the strategic dimensions of sales force compensation in distribution companies. In this regard, three research questions have been answered: What are the appropriate strategies for employee compensation? What are the strategic dimensions of sales force compensation? What is the status of the study population regarding compensation? The study population consisted of sales managers in oil products distribution companies, academic professors in the field of marketing and sales at expert judgment department, 120 sales force and managers working in 20 oil products distribution companies. For statistical analysis, the Delphi method, analysis of means, binomial test and Friedman test were used. The results have shown that initially 16 strategies out of 40 proposed strategic reference points and then 17 approved strategic reference points in the sales force compensation section can be derived among which the following strategy held the top rating, "sales force compensation for services should be based on motivating factors in order to improve the competitive environment among employees and improve their sales performance". Moreover, in terms of compensation strategy, the appropriateness of compensation for incentive service of sales force in the studied companies was at a favorite level.
\end{abstract}

Keywords. compensation, sales force, compensation strategy, distribution companies

\section{Introduction}

A proper strategic system in the context of compensation can create a competitive advantage for the organization; accordingly, nowadays organizations are facing various issues due to the lack of a fair and integrated compensation system (Redmond and Wilkinson, 2009).

Sales-oriented organizations (distribution companies) require a variety of different subsystems in order to manage human resources (HR) as their most valuable resources. The efficiency of these subsystems is associated with the coordination among them. Meanwhile, the compensation subsystem as one of the main HR management subsystems in these companies requires the strategic planning of sales forces through coordination among different sectors of compensation such as the design of salary systems, reward systems, 
classification and evaluation of jobs, etc., in order to provide appropriate strategic lines to design each of these sectors coordinately. These points and lines of strategic reference help sales-oriented organizations how to choose the proper strategies and policies for each organizational element or system of sales in order to be coordinated with the strategies and policies of other sales elements (Fiegenbaum et al.,1996).

However, an overwhelming majority of Iranian companies lack such an approach toward their human resources systems. In these companies (especially sales-oriented and distribution companies), the lack of a strategic and long-term vision for human resources management can be observed in the subsystem of compensation. This fact has a negative effect on the accurate planning of entrance, maintenance and termination processes of sales force in these organizations which will result in the decrease of productivity and efficiency as well as the failure of organization's mission to increase sales. Studies have shown that due to a high gap between the incomes of line and force workers and also the lack of a proper strategy in wages and salaries payment system, sale-oriented companies face problems such as a lack of incentive and commitment of sales force toward the organization. This issue itself results from the lack of or inadequate HR management attention to identify the strengths and weaknesses of compensation systems.

To confirm this issue, interviews with company managers also indicate this chronic issue in the abovementioned organizations. Moreover, sales forces' dissatisfaction regarding wages and salaries payment method leads to turnover intention and unproductive work in the organization and makes it difficult for the organization to achieve its goals. Therefore, the current study seems significant since the scientific and theoretical explanation of sales forces' compensation activities improvement in wage payment sector and incentive systems for distribution companies' employees is a scientific necessity. On the other hand, providing practical and executive solutions for this subsystem in distribution companies is an executive and operational necessity in the field of HR management in order to improve sales forces compensation which ultimately results in higher performance of sales force and achieving competitive advantage in the market. Therefore, the main purpose of the present study is to identify the strategic dimensions of sales force compensation in sales-oriented organizations (distribution companies) and select (develop) a suitable employee compensation strategy.

\section{Literature Review}

\subsection{Strategic reference points (SRP)}

Strategic reference points (SRP) are "outstanding objectives or patterns that organizational decision makers use to assess their approaches or options so that they can thereby adopt strategic decisions and provide the main beneficiary groups with the priorities of the whole system" (Bamberger \& Meshoulam, 2000). In fact, a reference point is a location or a point in comparison to which all calculations and choices are measured (Eskafi, 2005). The organization selects strategic reference points in order to achieve strategic coordination or perform appropriate actions and operations (Fiegenbaum et al., 1996). In other words, strategic reference points are points of coordination and if all organization elements and systems are in alignment with it, a comprehensive coordination will be achieved (E'rabi, 2006). In defining HR strategy and its subsystems, one can identify and implement appropriate strategies for the desired organization through identification of primary and secondary strategic reference points and their coordinates. 


\subsection{Human Resources (HR) Strategy}

In an organization, the strategic HR management as a method in the process of managing individuals cannot be unrelated to HR strategy. In fact, the process of developing and implementing HR strategy in order to link HR policies and practices with strategic and organization goals is the main pillar of strategic human resource management (HRM). Therefore, if strategic HRM is "the process through which an organization seeks to link the human, social, and intelligence capital of their members to the strategic needs of the firm; consistently, HR strategy as a component or a part of the organization becomes a road map which organizational leaders use to maintain this relationship, and HR strategy is the road that is actually traveled" (Bamberger and Meshoulam, 2000).

\subsection{Integrated Model of HR Strategy Development}

Strategic reference points approach enables strategy designers to benefit from both previous patterns and determine the overall system priorities using core criteria as well as incorporating these overall priorities into the strategy so that all stakeholder groups are guided and managed in accordance with the desired principles and basics. Using the attractive logic of combinative research, Bamberger and Meshoulam (2000) proposed the application of strategic reference points (SRPs) to develop human resource strategy by introducing an 'integrated model'. The integrated model was formed via integrating the models based on personnel control, and those based on the labor market. According to this model, the decision-making model for choosing a HR strategy has two main questions as the strategic reference points. Providing answers for these two questions, four different HR strategies are achieved as shown in Table 1 (Bamberger \& Meshoulam, 2000).

Table 1. Integrative Model of Human Resource Strategy Formulation (Bamberger et al., 2000).

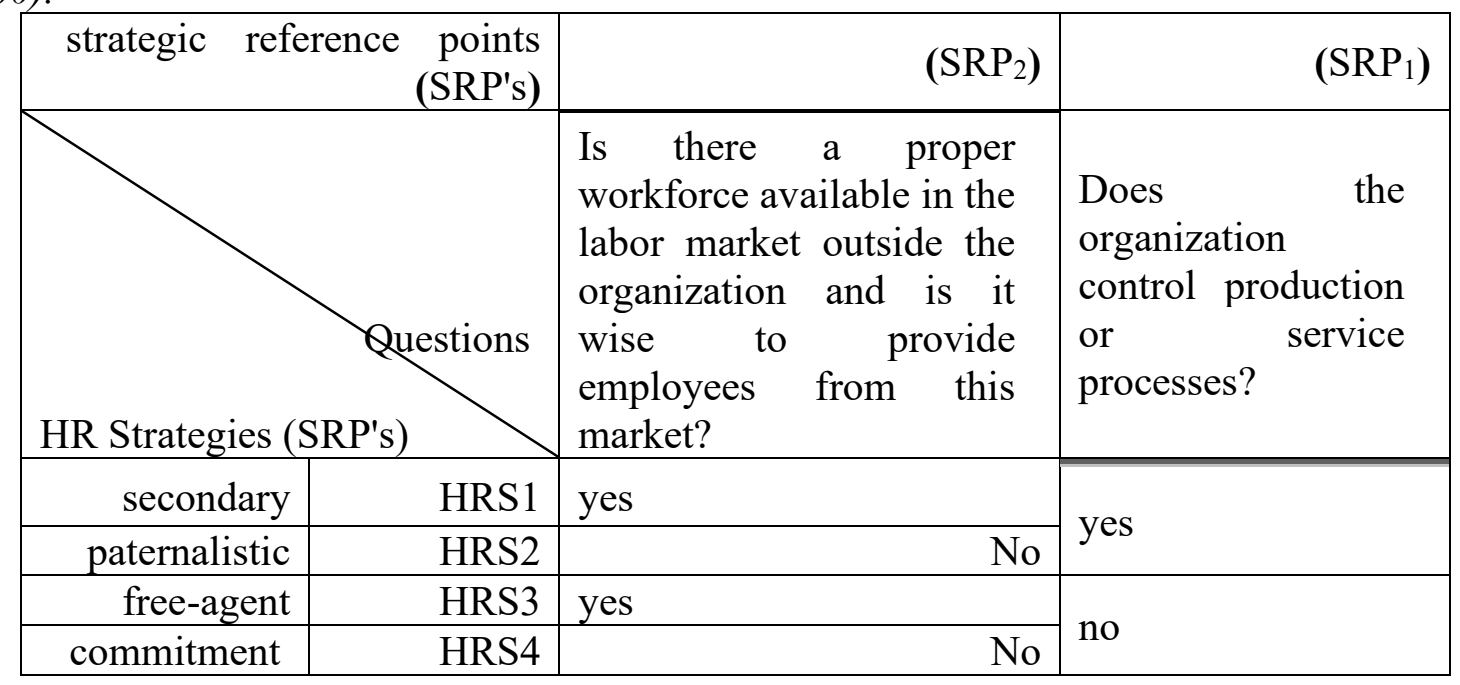

\subsection{Compensation strategies}

Compensation strategy determines how the organization responds to employees' efforts and it is strongly influenced by HR policies of the business world. Compensation strategy provides answers for two basic questions:

1. Should the company attract elites of job market with maximum payment or should it seek to attract job market newcomers with lower payments and higher training costs?

2. Does the company tend to concentrate compensation on wages and salaries or use its bargaining power as a major buyer and offer cheap benefits to employees? 
Answering these questions determine the company's appropriate position in the job market. The appropriate position can be defined as median graphs of active companies' payment in the market or as different income/group deciles. This position is defined as a desirable condition, according to which the salary table for different job groups is defined. Then, the gap between internal payment and the line of desired condition is modified according to the anticipation of required budget and its implementation. In their book, Stewart and Brown (2008) define strategy as a determinant of where we are going to and how we want to reach our destination. According to this definition, one may conclude that "compensation strategy" is the strategy that determines employee's incentive package. This strategy may differentiate between organizations, groups of employees, and even employees themselves (Redman \& Wilkinson, 2009).

According the above definitions of compensation strategy, some strategies derived from library resources and in accordance with existing conditions are as follows:

1. Variable performance-based compensation versus fixed compensation (E'rabi and Moghaddam, 2007; Stewart \& Brown, 2009);

Another kind of variable compensation is based on the organization's performance which is performed in an attempt to align the value of employees and those of the organization such as the payment method in a variety of profit sharing programs. Organizations that have a differentiation strategy will form most of their incentive rewards on the basis of individual performance.

2. Transactional compensation (short horizon) versus relational compensation (long horizon) (Stewart and Brown, 2009);

In relational compensation, social ties are more important than monetary incentives. In this type of relationship, employees feel a sense of belonging because they have worked in the organization for a long time. The organization also uses benefits and rewards to build a sense of camaraderie and support among the employees. In transactional compensation, monetary and financial incentives are highlighted. In this type of relationship, employees are motivated by short-term rewards. Management also uses rewards to encourage individuals to try harder. In this type of relationship, employees are not expected to develop a long-term corporation with the organization.

3. Individual versus group performance-based compensation (Redman and Wilkinson, 2009);

A group performance-based strategy as counterpart to an individual performance-based strategy aims to identify the expected outcomes of a group, encourage them and value the efficiency of group performance. Obviously, its implementation - particularly in countries with high levels of individualism - will be difficult and it has been implemented only in a small number of organizations so far (Redman and Wilkinson, 2009). It should be noted that some previous studies have considered higher productivity to be the effect of individual performance-based compensation variable in comparison to group performance-based compensation variable; however, they noted that this hypothesis should be tested in different environments, different organizational conditions and with different individuals in order to review all results (Stewart \& Brown, 2009). Group reward is paid to the group members once the whole group have a high performance. This strategy will work better when the size of the group is relatively small, its performance can be accurately calculated, and the senior management fully supports the program (Stewart \& Brown, 2009). 


\subsection{Developing Strategic Reference Points for Sales Force}

Since the current research seeks to develop compensation strategies based on strategic reference points in sales force and companies; consequently, two categories of strategic reference points can be used to modify and improve compensation strategies in these companies:

1. Sales strategies as strategic reference points of sales force performance in distribution companies:

The current approach to sales strategy claims that this concept has gone beyond the management of sales forces and is now related to the overall management of sales-related activities (Zoltners et al., 2009). This view allows sales managers to conceptualize sales strategy at the level of sales-related activities and not just at the operational levels of the company (Johnston \& Marshall, 2009).

Market segmentation is the process of subdividing a market into distinct subsets of customers that have similar behaviors and needs. Market targeting is performed after market segmentation and involves the evaluation and comparison of identified groups and the selection of one or more groups with higher potentials. Thus, the second step is to define different groups of customers, prioritize them based on their potential importance for the company, and match sales activities to each third dimension, i.e. development with each group of customers (Keegan \& Schlegelmilch, 2001). Communication goals and sales patterns are the systematic actions a company is engaged in so as to develop communication goals and different sales patterns to address each customer (Spiro et al, 2008). Communication goals of sales patterns are constantly changing, including a variety of pure transactional exchanges to collaborative exchanges. Finally, the fourth dimension is the systematic use of multiple sales channels (such as sales force, distributors, telemarketing, Internet, etc.) which a company uses to manage sales activities and meet the needs of customers more efficiently (Zoltner et al., 2009).

Combining different studies on sales strategies, we can focus on two categories of sales strategies:

Table 2. Sales strategies (Dehdashti, Shahrokh \& Pourhoseini, 2013).

\begin{tabular}{|l|l|l|l|}
\hline Sales strategy & Corporate level & $\begin{array}{l}\text { Sales-person } \\
\text { level }\end{array}$ & Resource \\
\hline Customer segmentation targeting and & $*$ & & Weitz (1978) \\
\hline $\begin{array}{l}\text { Customer sujan, } \\
\text { adjusting sales practices }\end{array}$ & $*$ & $*$ & $\begin{array}{l}\text { Weitz, } \\
\text { Sujan } \\
(1986)\end{array}$ \\
\hline $\begin{array}{l}\text { Communicational goals and } \\
\text { sales patterns }\end{array}$ & $*$ & & $\begin{array}{l}\text { De Vincentis, } \\
\text { Rackham (1999) }\end{array}$ \\
\hline $\begin{array}{l}\text { Use of multiple sales channels } \\
\text { Observation/compensation/sales } \\
\text { control systems }\end{array}$ & $*$ & $\begin{array}{l}\text { Fang, Evans, } \\
\text { Landry } \\
(2005)\end{array}$ \\
\hline
\end{tabular}




\begin{tabular}{|l|l|l|l|}
\hline Presenting values & $*$ & & $\begin{array}{l}\text { ChrzanowskiLeigh } \\
(1998)\end{array}$ \\
\hline Sales force process/behaviors & & $*$ & $\begin{array}{l}\text { Oliver, Anderson } \\
(1994)\end{array}$ \\
\hline $\begin{array}{l}\text { Developing a sale management } \\
\text { plan }\end{array}$ & $*$ & & $\begin{array}{l}\text { ChrzanowskiLeigh } \\
(1998)\end{array}$ \\
\hline
\end{tabular}

2. Key factors for the success of sales force performance as the strategic reference points for sales force in distribution companies:

In various studies, some factors have been mentioned for performance of sales forces. It can be noted that according to "self-determination theory (SDT)" and basic "physiological needs", human beings have three essential requirements that must be fulfilled first in order to for the other needs to be met. According this theory, providing and meeting the basic physiological needs provides the required nutrition for intrinsic motivation and internalization. The three basic physiological requirements are autonomy, competence, and relatedness. Providing these three needs will lead to individual growth. Although there has been much debate about the usefulness of this concept, physiological needs concept has been the focus of organizational behavior studies for decades. In traditional organization studies, the power of 'need' have been evaluated and its effect has been studied either directly or in relation to job characteristics to predict motivation, job satisfaction and job outcomes (Hall, 2001).

\section{Research Methodology}

This study is an applied research in terms of purpose, a descriptive survey of exploratory type in terms of nature; and is conducted in three steps. In the first step, once the theoretical foundations were reviewed, the strategic dimensions of compensation for sales force have been identified. In this step, an exploratory analysis of Delphi's method has been used to identify the most important dimensions of strategic compensation. In the second step, a survey was used to extract compensation strategies in sales-oriented companies and rank them based on strategic reference points from their sales force's point of view. In the third step, the status of studied companies was examined in terms of compensation for vendors based on the extracted strategies; moreover, the status of implementation of these strategies were examined. The aim of the present study was to answer the following questions:

- What are the appropriate strategies for employee compensation?

- What are the strategic dimensions of sales force compensation?

- What is the status of the study population regarding compensation for services?

The statistical population of the research can be explained in two stages:

- In the section related to exploratory analysis of Delphi method and identification of the most important strategic reference points in studied organizations, the statistical population of the study included 10 sales managers in distribution companies and 4 university professors in the field of marketing and sales.

- At the stage of extracting compensation strategies by evaluating strategic reference points of confirmed compensations from the perspective of sales force, the statistical population of 
the study included a number of 20 oil product distribution companies. After making the necessary arrangements, the managers and the sales force of these companies have been surveyed using the two study questionnaires. These companies maintained a number of 200 managers and sales force.

For the first study questionnaire, namely, a Delphi survey concerning experts and in order to identify the most important strategic reference points for compensation, no sampling has been carried out and all 15 experts mentioned in the statistical population were studied. In the second study questionnaire, i.e. questioning sales managers and sales force in oil product distribution companies, the sampling method was a simple random sampling, i.e. all employees and managers of the statistical population had equal chance when responding to the questions of the second questionnaire. The statistical population determined for the current study was equal to a number of 200 individuals based on collected information. According to Cochran's sample size formula, $(\mathrm{Cl}=95 \%)$, a number of 131 participants is enough for a statistical population of 200. Accordingly, a number of 140 questionnaires were distributed among the above-mentioned companies, and finally 120 questionnaires were completed and applicable to be used in statistical tests of the study. To determine the reliability of the first questionnaire, Cronbach's alpha $(\alpha)$ has been calculated using SPSS software. The results of reliability measurement are presented in Table 3:

Table 3. Reliability of the variables related to the second study questionnaire

\begin{tabular}{|l|l|l|l|l|}
\hline Variables & $\begin{array}{l}\text { Cronbach's } \\
\text { alpha } \\
\text { coefficient }\end{array}$ & $\begin{array}{l}\text { Number of } \\
\text { questions }\end{array}$ & $\begin{array}{l}\text { Standard } \\
\text { range }\end{array}$ & $\begin{array}{l}\text { Reliability } \\
\text { confirmation }\end{array}$ \\
\hline $\begin{array}{l}\text { Strategic reference } \\
\text { points based on } \\
\text { compensation } \\
\text { practices in sales- } \\
\text { oriented companies }\end{array}$ & 0.779 & 6 & above 0.7 & confirmed \\
\hline $\begin{array}{l}\text { Sales strategies in } \\
\text { sales-oriented } \\
\text { companies }\end{array}$ & 0.718 & 2 & above 0.7 & confirmed \\
\hline $\begin{array}{l}\text { Key elements of } \\
\text { sales force's } \\
\text { success }\end{array}$ & 0.751 & 3 & above 0.7 & confirmed \\
\hline $\begin{array}{l}\text { Factors suggested } \\
\text { by experts }\end{array}$ & 0.743 & 5 & above 0.7 & confirmed \\
\hline Overall reliability & 0.791 & 16 & above 0.7 & confirmed \\
\hline
\end{tabular}

In order to measure the validity of the first study questionnaire, the authors refer to the standard and valid sources which have been used in this study. To test the validity of the second questionnaire, face and content (logical) validity has been used.

\section{(a) 3.1. Data Collection and Analysis}

This research consists of 6 executive steps which are discussed below:

Step 1: Reviewing the internal and external literature and identifying strategic reference points for sales force compensation; 
In order to provide an answer for the first study question, i.e. the appropriate strategic reference points for sales force compensation in sales-oriented companies, a substantial body of literature related to compensation management and its benefits, developed patterns, and models in organizations has been reviewed. Finally, three categories of strategic reference points for sales force compensation (sales strategies for sales-oriented organizations, key factors of sales force success, and methods of compensation for sales forces in sales-oriented organizations) have been extracted from these studies.

Step 2: Identifying the most important strategic reference points for sales force from experts' perspective;

In this step, the components of identified reference points categories from the previous step were organized in the form of the first study questionnaire and the experts (e.g. senior managers and sales experts in distribution companies as well as university professors in the field of sales and marketing) were asked to choose the most important points that they believe to be the best strategic reference points in the development of compensation strategies. At the end of the questionnaire, participants were asked to identify other strategic reference points they believe to be relevant in development of compensation strategies for sales-oriented companies that were not included in the study questionnaire.

Step 3: Identifying the most important identified strategic reference points using the Delphi exploratory analysis method;

The data collected from the first questionnaire using the Delphi method were analyzed and the most important strategic reference points for sales force compensation were determined from the experts' perspective.

Step 4: Developing the second study questionnaire and surveying the statistical sample to identify the appropriate strategies for compensation in sales-oriented companies;

The most important reference points identified by the Delphi method are organized in form of the main questionnaire with a five-point Likert scale (strongly disagree, disagree, neutral, agree, and strongly agree) and are measured in the second-phase research sample.

Step 5: Analyzing the questionnaire's data with respect to descriptive statistics and central and dispersion parameters;

The collected data from the second questionnaire were analyzed based on descriptive analysis (for statistical analysis, the Delphi method, analysis of means, binomial test and Friedman test were used) to determine whether studied employees and sales force emphasized on and responded to which specified scenarios for strategic reference points in the questionnaires.

Step 6: Extracting strategies based on the results of descriptive analysis;

Based on the results of the previous step regarding sales force thoughts on strategic reference points for compensation, these strategies have been extracted for sales-oriented companies.

\section{Research Results}

In the present research, the Delphi method was used to identify the most important strategic reference points for sales force compensation in sales-oriented companies among identified factors obtained from the literature review. For this purpose, according to the Delphi questionnaire of the study, a number of 23 factors have been extracted from the literature review. A questionnaire was distributed among 14 expert sales managers in oil product distribution companies and 4 university professors in the field of marketing and sales. The Delphi analysis was conducted in two steps to identify the most important strategic reference points as follows: 


\subsection{The first phase of analyzing the Delphi method}

In the first phase, a questionnaire was distributed among 14 experts which involved 23 questions (strategic point of reference) and one open-ended question. The experts were asked to add additional strategic reference points in the compensation section of sales force based on their own experiences and provide answer for all 23 questions based on their experiences and knowledge so as to indicate the extent to which they agree or disagree (i.e. strongly agree, agree, neutral, disagree, strongly disagree) with these components to be the most important strategic reference points for sales force compensation. Subsequently, the results of experts' ratings were determined by calculating the standard deviation of responses. At this phase, we eliminated the components with a standard deviation $(\sigma)$ higher than 1 (in the extreme sides) which were not favorable with one another to a large extent and the rest of strategic reference points $(\sigma<1)$ were accepted. The related results are presented in Table 4:

Table 4. The first phase of analyzing the Delphi method results

\begin{tabular}{|c|c|c|}
\hline $\begin{array}{l}\text { Component } \\
\text { No. }\end{array}$ & Strategic reference point & $\begin{array}{l}\text { Standard } \\
\text { deviation }\end{array}$ \\
\hline 1 & $\begin{array}{l}\text { Monetary rewarding and compensation practices } \\
\text { must vary for employee in different sectors } \\
\text { including sales sector, communications department, } \\
\text { etc. }\end{array}$ & 0.479157 \\
\hline 2 & $\begin{array}{l}\text { It seems that a suitable combination of base salaries } \\
\text { and sale commission for sales force should be } \\
\text { considered in accordance with different conditions } \\
\text { of the company (e.g. the start-up stages, the intense } \\
\text { competitive stage in the market, market downturn } \\
\text { stage, etc.) }\end{array}$ & 0.772618 \\
\hline 3 & $\begin{array}{l}\text { The effect of sales force quantity on sales volume } \\
\text { depends on the conditions of the company. This } \\
\text { effect is high in the early stages of company's } \\
\text { starting activities and low in the consolidation and } \\
\text { maturity stages. }\end{array}$ & 1.11575 \\
\hline 4 & $\begin{array}{l}\text { Introducing the company and improving its brand } \\
\text { reputation among customers is more important than } \\
\text { high sales volume. }\end{array}$ & 1.195229 \\
\hline 5 & $\begin{array}{l}\text { Aligning sales volume with the vision and mission } \\
\text { of the company in the market is more important } \\
\text { than the sales volume itself. }\end{array}$ & 0.820652 \\
\hline 6 & $\begin{array}{l}\text { Flexibility in compensation for sales force and } \\
\text { rewarding them is very important. }\end{array}$ & 0.742307 \\
\hline 7 & $\begin{array}{l}\text { Along with the main duty of a salesperson, other } \\
\text { duties such as considering customer needs as well } \\
\text { as providing products with high quality (not any } \\
\text { kind of a product) are more important than sales } \\
\text { volume. }\end{array}$ & 1.08091 \\
\hline
\end{tabular}




\begin{tabular}{|c|c|c|}
\hline 8 & $\begin{array}{l}\text { Creating and maintaining a good relationship with } \\
\text { customers is more important than high sales } \\
\text { volume. }\end{array}$ & 0.894997 \\
\hline 9 & $\begin{array}{l}\text { The effect of strong financial and moral rewards } \\
\text { (such as providing job opportunities for } \\
\text { salespersons, monetary and non-monetary prizes, } \\
\text { etc.) for compensation of sales force is significant } \\
\text { regarding the issue of sales performance } \\
\text { improvement. }\end{array}$ & 0.610286 \\
\hline 10 & $\begin{array}{l}\text { Group appreciation and encouragement are more } \\
\text { important than individual ones when rewarding } \\
\text { sales force. }\end{array}$ & 1.301491 \\
\hline 11 & $\begin{array}{l}\text { The sales force who focus on customer } \\
\text { segmentation should receive more pay and benefits. }\end{array}$ & 0.145085 \\
\hline 12 & $\begin{array}{l}\text { The sales force who focus on adjusting their sales } \\
\text { practices with customers should receive more pay } \\
\text { and benefits. }\end{array}$ & 1.160577 \\
\hline 13 & $\begin{array}{l}\text { The sales force who focus on communication } \\
\text { objectives during sales should receive more pay and } \\
\text { benefits. }\end{array}$ & 1.049781 \\
\hline 14 & $\begin{array}{l}\text { The sales force who learn new sales patterns and } \\
\text { use them during sales should receive more pay and } \\
\text { benefits. }\end{array}$ & 0.812444 \\
\hline 15 & $\begin{array}{l}\text { The sales force who uses different communication } \\
\text { practices during sales should receive more pay and } \\
\text { benefits. }\end{array}$ & 1.160577 \\
\hline 16 & $\begin{array}{l}\text { Sales force who value customers during sales } \\
\text { should have more pay and benefits. }\end{array}$ & 1.049781 \\
\hline 17 & $\begin{array}{l}\text { The sales manager must perform compensation for } \\
\text { sales force with respect to their performance which } \\
\text { is in accordance with company's predetermined } \\
\text { sales plans. }\end{array}$ & 0.92582 \\
\hline 18 & $\begin{array}{l}\text { Compensation for sales force should be based on } \\
\text { their competency needs (salespersons with more } \\
\text { competency needs require more compensation and } \\
\text { those with less competency needs must receive less } \\
\text { compensation). }\end{array}$ & 1.277753 \\
\hline 19 & $\begin{array}{l}\text { Compensation for sales force should be based on } \\
\text { their communication needs (salespersons in need } \\
\text { for more human communications require more } \\
\text { compensation and those in need of less human } \\
\text { communications must receive less compensation). }\end{array}$ & 1.160577 \\
\hline 20 & $\begin{array}{l}\text { Compensation for sales force should be based on } \\
\text { their collective efficacy in terms of their unit's sales } \\
\text { efficiency. }\end{array}$ & 0.894997 \\
\hline 21 & $\begin{array}{l}\text { Compensation for sales force should suits their } \\
\text { level of competition with other salespersons in }\end{array}$ & 1.118034 \\
\hline
\end{tabular}




\section{(1i) TECHNIUM}

Technium Social Sciences Journal

Vol. 3, 112-140, February 2020

ISSN: 2668-7798

www.techniumscience.com

\begin{tabular}{|l|l|l|}
\hline & order to improve their sales performance. & \\
\hline 22 & $\begin{array}{l}\text { Compensation for sales force should be based on } \\
\text { motivating factors which enhances the competitive } \\
\text { atmosphere among employees and improves their } \\
\text { sales performance. }\end{array}$ & 0.772618 \\
\hline 23 & $\begin{array}{l}\text { Compensation for sales force should be based on } \\
\text { freedom of action provided by the company in order } \\
\text { for the employees to sell products in a more } \\
\text { creative way and improve their sales performance. }\end{array}$ & 0.880631 \\
\hline
\end{tabular}

According to the results of the first phase in Table 4, the strategic reference points in the first questionnaire (items $3,4,7,10,11,12,13,15,16,18,19$, and 21 , respectively) with a standard deviation greater than $1(\sigma>1)$ showed a high dispersion in the comments given by 14 experts; subsequently, they were eliminated at this phase. Finally, since the experts were asked to provide other points of reference rather than those proposed in the research using their own experiences and knowledge; accordingly, a number of 17 reference points were suggested by the experts which are presented in the following phase.

\subsection{The second phase of analyzing Delphi method}

A number of seventeen factors suggested by the experts in the previous phase along with eleven factors accepted during first phase of Delphi analysis were all presented to the same 14 participants in form of a new questionnaire with the same style of the first questionnaire. Once again, the experts were asked to declare their agreement or disagreement regarding these reference points a more rigorous judgment. This time, factors with a standard deviation below 0.8 were confirmed and reference points with a standard deviation greater than 0.8 were rejected. The results are presented in Table 5.

Table 5. The second phase of analyzing the Delphi method results

\begin{tabular}{|l|l|l|}
\hline $\begin{array}{l}\text { Component } \\
\text { No. }\end{array}$ & Strategic reference point & $\begin{array}{l}\text { Standard } \\
\text { deviation }\end{array}$ \\
\hline 1 & $\begin{array}{l}\text { Monetary rewarding and compensation practices } \\
\text { must vary in different sectors including sales sector, } \\
\text { communications department, etc. }\end{array}$ & 0.479157 \\
\hline 2 & $\begin{array}{l}\text { It seems that a suitable combination of base salaries } \\
\text { and sale commission for sales force should be } \\
\text { considered in accordance with different conditions } \\
\text { of the company (e.g. the start-up stages, the intense } \\
\text { competitive stage in the market, market downturn } \\
\text { stage, etc.) }\end{array}$ & 0.755929 \\
\hline 5 & $\begin{array}{l}\text { Aligning sales volume with the vision and mission } \\
\text { of the company in the market is more important } \\
\text { than the sales volume itself. }\end{array}$ & 0.717848 \\
\hline 6 & $\begin{array}{l}\text { Flexibility in compensation for sales force and } \\
\text { rewarding them is very important. }\end{array}$ & 0.59333 \\
\hline 8 & $\begin{array}{l}\text { Creating and maintaining a good relationship with } \\
\text { customers is more important than high sales }\end{array}$ & 0.794497 \\
\hline
\end{tabular}




\begin{tabular}{|c|c|c|}
\hline & volume. & \\
\hline 9 & $\begin{array}{l}\text { The effect of strong financial and moral rewards } \\
\text { (such as providing job opportunities for } \\
\text { salespersons, monetary and non-monetary prizes, } \\
\text { etc.) for compensation of sales force is significant } \\
\text { regarding the issue of sales performance } \\
\text { improvement. }\end{array}$ & 0.610286 \\
\hline 14 & $\begin{array}{l}\text { The sales force who learned new sales patterns and } \\
\text { used them during sales should receive more pay and } \\
\text { benefits. }\end{array}$ & 0.793229 \\
\hline 17 & $\begin{array}{l}\text { The sales manager must perform compensation for } \\
\text { sales force with respect to their performance which } \\
\text { is in accordance with company's predetermined } \\
\text { sales plans. }\end{array}$ & 0.72582 \\
\hline 20 & $\begin{array}{l}\text { Compensation for sales force should be based on } \\
\text { their collective efficacy in terms of their unit's sales } \\
\text { efficiency. }\end{array}$ & 0.794988 \\
\hline 22 & $\begin{array}{l}\text { Compensation for sales force should be based on } \\
\text { motivating factors which enhances the competitive } \\
\text { atmosphere among employees and improves their } \\
\text { sales performance. }\end{array}$ & 0.772618 \\
\hline 23 & $\begin{array}{l}\text { Compensation for sales force should be based on } \\
\text { provided freedom of action in order for the } \\
\text { employees to sell products in a more creative way } \\
\text { and improve their sales performance. }\end{array}$ & 0.660631 \\
\hline 24 & $\begin{array}{l}\text { It is better to offer more compensation to } \\
\text { salespersons who consider finding new customers } \\
\text { and developing the market. }\end{array}$ & 1.04217 \\
\hline 25 & $\begin{array}{l}\text { It is better to offer more compensation to } \\
\text { salespersons who pay more attention to increasing } \\
\text { sales and penetrating the market. }\end{array}$ & 1.052209 \\
\hline 26 & $\begin{array}{l}\text { It is better to offer more compensation to } \\
\text { salespersons who pay more attention to selling all } \\
\text { company products (product portfolio) to customers } \\
\text { and diversifying their sales. }\end{array}$ & 1.11575 \\
\hline 27 & $\begin{array}{l}\text { It is better to offer more compensation to } \\
\text { salespersons who pay more attention to new or slow } \\
\text { selling products. }\end{array}$ & 0.771534 \\
\hline 28 & $\begin{array}{l}\text { Compensation for sales force should be partly based } \\
\text { on collective efficacy and partly on individual } \\
\text { efficacy. }\end{array}$ & 1.277753 \\
\hline 29 & $\begin{array}{l}\text { More monetary compensation must be offered to } \\
\text { salespersons who represent the organization's brand } \\
\text { in a more proper way (since the correct presentation } \\
\text { of the brand guarantees stable sales). }\end{array}$ & 1.17803 \\
\hline 30 & $\begin{array}{l}\text { The training of sales force in technical and } \\
\text { specialized fields via training seminars will result in }\end{array}$ & 1.124825 \\
\hline
\end{tabular}




\begin{tabular}{|c|c|c|}
\hline & $\begin{array}{l}\text { the success and increase of the compensation level } \\
\text { in the organization. }\end{array}$ & \\
\hline 31 & $\begin{array}{l}\text { Participation of sales forces in rhetoric and } \\
\text { marketing seminars will result in the increase of the } \\
\text { compensation level in the organization. }\end{array}$ & 0.626753 \\
\hline 32 & $\begin{array}{l}\text { Holding weekly meetings and listening to the needs } \\
\text { of employees and trying to meet those needs will } \\
\text { increase the compensation level in the organization. }\end{array}$ & 1.042466 \\
\hline 33 & $\begin{array}{l}\text { The presence of challenging tasks and providing } \\
\text { growth opportunities for salespersons will increase } \\
\text { the compensation level in the organization. }\end{array}$ & 0.717848 \\
\hline 34 & $\begin{array}{l}\text { The presence of floating work schedules and } \\
\text { favorable working environment will increase sales. }\end{array}$ & 1.184521 \\
\hline 35 & $\begin{array}{l}\text { Offering monetary rewards to salespersons for } \\
\text { positive innovations in sales will increase the } \\
\text { compensation level in the organization. }\end{array}$ & 0.720652 \\
\hline 36 & $\begin{array}{l}\text { Paying attention to moral and affective needs of } \\
\text { personnel and satisfying them to the possible extent } \\
\text { will increase the compensation level in the } \\
\text { organization. }\end{array}$ & 1.042466 \\
\hline 37 & $\begin{array}{l}\text { Paying attention to the efficiency of personnel and } \\
\text { increasing their salaries in proportion to their } \\
\text { efficiency will increase the compensation level in } \\
\text { the organization. }\end{array}$ & 0.758315 \\
\hline 38 & $\begin{array}{l}\text { Paying attention to employees' level of education } \\
\text { and satisfying them in terms of job satisfaction and } \\
\text { organizational position according to their level of } \\
\text { education will increase the compensation level in } \\
\text { the organization (that is, if their level of education } \\
\text { has had a positive effect on their work process). }\end{array}$ & 1.301491 \\
\hline 39 & $\begin{array}{l}\text { Organizational justice towards salespersons will } \\
\text { increase the compensation level in the organization. }\end{array}$ & 1.145551 \\
\hline 40 & $\begin{array}{l}\text { Listening to employees' financial and moral needs } \\
\text { (trying to make sure employees understand that the } \\
\text { manager cares about their presence in the } \\
\text { organization which is essential for the company) } \\
\text { will increase the compensation level in the } \\
\text { organization. }\end{array}$ & 0.772618 \\
\hline
\end{tabular}

Based on the results presented in Table 5, in the second phase, in order to create more convergence between the 28 components, a number of 11 reference points were omitted due to a standard deviation greater than 0.8 . As it can be seen in the previous phase, 17 strategic reference points out of the 40 strategic reference points identified in the exploratory analysis of Delphi method were confirmed by the experts. These 17 reference points were organized as the main points for a survey of sales force and marketing managers in studied salesoriented companies in the second study questionnaire. The second questionnaire contains 16 questions related to 16 approved strategic reference points. It should be noted that since the 
strategic reference points of No. 14, "the sales force who learned new sales patterns and used them during sales should receive more pay and benefits", and No. 35, "offering monetary rewards to salespersons for positive innovations in sales will increase the compensation level in the organizations", contain the same meaning; consequently, only one question was dedicated to both of them in the second research questionnaire.

\section{Answering the first research question: What are the appropriate strategic dimensions for sale force compensation?}

Table 6. Mean of responses given by sales force regarding strategic reference points for compensation

\begin{tabular}{|c|c|c|}
\hline & Strategic reference point & $\begin{array}{l}\text { Mean of } \\
\text { given } \\
\text { responses } \\
\text { by sales } \\
\text { force }\end{array}$ \\
\hline 1 & $\begin{array}{l}\text { How should the methods of monetary remuneration and } \\
\text { compensation for employees in this company differ } \\
\text { according to the type of their departments such as } \\
\text { departments of sales, communications, finances, etc.? }\end{array}$ & 4.7667 \\
\hline 2 & $\begin{array}{l}\text { Is an appropriate mix of base salaries and sales commission } \\
\text { for salespersons in accordance with different company } \\
\text { conditions (e.g. the start-up stages, the intense competitive } \\
\text { stage in the market, market downturn stage, etc.) a good } \\
\text { compensation practice? }\end{array}$ & 4.8083 \\
\hline 3 & $\begin{array}{l}\text { Do you consider it important for the sales volume of your } \\
\text { company to be in line with the achievement of company's } \\
\text { goals regarding the market even if the sales volume is not } \\
\text { high? Or do you consider the volume of sales as the only } \\
\text { important matter (i.e. the more sales, the better)? }\end{array}$ & 3.1167 \\
\hline 4 & $\begin{array}{l}\text { Do you think the company should consider a link between } \\
\text { the efforts of sales force and compensation, or should it } \\
\text { only provide base salary and typical rewards? }\end{array}$ & 3.9333 \\
\hline 5 & $\begin{array}{l}\text { To what extent do you agree with the view that establishing } \\
\text { and maintaining a good relationship with customers during } \\
\text { sales is important? }\end{array}$ & 3.2417 \\
\hline 6 & $\begin{array}{l}\text { How do you think significant financial and moral rewards } \\
\text { (such as providing job opportunities for salespersons, } \\
\text { monetary and non-monetary prizes, etc.) for sales force } \\
\text { compensation affect their performance regarding sales } \\
\text { volume? }\end{array}$ & 4.2917 \\
\hline 7 & $\begin{array}{l}\text { Do you think salespersons who learned new sales patterns } \\
\text { and used these patterns or their own innovations during } \\
\text { sales should receive more pay and benefits in comparison } \\
\text { to others? }\end{array}$ & 4.2500 \\
\hline 8 & To what extent do sales managers need to offer sales force & 2.1667 \\
\hline
\end{tabular}




\begin{tabular}{|c|c|c|}
\hline & $\begin{array}{l}\text { compensation with respect to their performance in } \\
\text { accordance with company's predetermined sales plans? }\end{array}$ & \\
\hline 9 & $\begin{array}{l}\text { Do you think sales force compensation should be based on } \\
\text { collective efficacy in terms of a sale unit's efficiency? Or } \\
\text { individual sales performance is more important? }\end{array}$ & 3.1500 \\
\hline 10 & $\begin{array}{l}\text { Would you support the view that compensation for the } \\
\text { sales force should be based on motivating factors in order } \\
\text { to enhance the competitive atmosphere among employees } \\
\text { and improve their sales performance? }\end{array}$ & 4.2583 \\
\hline 11 & $\begin{array}{l}\text { To what extent do you believe that sale force compensation } \\
\text { should be based on provided freedom of action in order for } \\
\text { the employees to sell products in a more creative way and } \\
\text { improve their sales performance? }\end{array}$ & 3.1417 \\
\hline 12 & $\begin{array}{l}\text { Do you think that salespersons who pay more attention to } \\
\text { new or slow selling products and try to reach higher sales } \\
\text { for these products should be taken into consideration when } \\
\text { judging about sales force compensation? }\end{array}$ & 4.3750 \\
\hline 13 & $\begin{array}{l}\text { To what extent do you believe that rewards should be } \\
\text { offered to salespersons who participate in rhetoric, } \\
\text { marketing, and sales techniques seminars? }\end{array}$ & 2.2000 \\
\hline 14 & $\begin{array}{l}\text { Should rewards be offered to salespersons who are } \\
\text { interested in and looking for challenging tasks and growth } \\
\text { opportunities regarding sales? }\end{array}$ & 4.4417 \\
\hline 15 & $\begin{array}{l}\text { Is it necessary to focus on the efficacy of salespersons in } \\
\text { difficult situations when considering pay raises and } \\
\text { rewards? }\end{array}$ & 4.4417 \\
\hline 16 & $\begin{array}{l}\text { How much do you agree that listening to employees' } \\
\text { financial and moral needs (making sure employees } \\
\text { understand that the manager cares about their presence in } \\
\text { the organization which is essential for the company) can be } \\
\text { effective in sale force compensation? }\end{array}$ & 3.1083 \\
\hline
\end{tabular}

Based on the mean of given responses regarding strategic reference points for compensation as shown in Table 6 and according to the options considered for each reference point, the following strategies were extracted:

1. The compensation structure must vary based on sales force and their positions, and the level of difference should be based on the difference between sales forces' relationship with the customers.

2. Instantaneous wage rates along with sales commissions must be paid to sales force. One must ensure that a suitable and incentive combination of salary and sales commission is developed based on sales conditions for sales force compensation.

3. Sales force compensation should be in line with both dimensions of "reaching a company's sales goals" and "volume of sales". In this regard, sales force performance must be compensated and rewarded equally with regard to sales volume increase, sales goals actualization and market share. 
4. Compensation for sales forces should be established with respect to their efforts and performance beyond assigned duties in the sales sector; one should not merely focus on the results of sales in this regard.

5. Compensation for salespersons should be based on establishing and maintaining a good relationship with customers during sales and the results of such a relationship for continuity of subsequent sales.

6. Strong non-monetary incentives should be used for salespersons compensation. Although this method is difficult to implement, it is suitable when there is a need to improve other methods of compensation using additional incentives.

7. Compensation and rewards for salespersons who learned new sales patterns and use these methods or their own innovations to increase sales should be the same amount as the compensation for those salespersons who increase the sales volume with the help of previous and pre-determined practices.

8. Sales management should perform sales forces compensation with respect to their performance when adapting to pre-determined sales plans of the company as well as their situational performance during unpredictable cases.

9. Sales force compensation should be based on both the effectiveness of their individual sales performance and their collective performance in the related sales unit.

10. Sales force compensation should be based on motivating factors in order to enhance competitive atmosphere among employees and improve their sales performance.

11. Sales force compensation should be moderately based on freedom of action for salespersons; meanwhile, the role of sales force performance on the basis of pre-determined goals should be considered in compensation decisions.

12. Compensation for salespersons should be considered in the light of their efforts regarding new or slow selling products; and a compensation should be considered for rewarding these additional efforts.

13. Sales force compensation should not necessarily be based on their participation in rhetoric, marketing, and sales techniques seminars, it should rather be based on the use of these techniques during sales (point of reference and the third strategy).

14. In order to compensate sales force who are interested in challenging tasks and growth opportunities regarding sales, extra rewards must be paid in addition to base salary.

15. In compensation for salespersons, one must focus on salespersons' efficiency during difficult selling situations and attempt to increase their salaries and rewards.

16. In compensation for salespersons, employers must focus on financial incentives alongside with moral incentives such as the presence of sales managers who listen to both financial and moral needs of the personnel.

\section{Answering the second research question: What are the appropriate strategies for sales force compensation?}

Table 7. Friedman test result

\begin{tabular}{ll}
\hline Numbers & 120 \\
\hline chi-squared $\left(\mathrm{x}^{2}\right)$ & 76.247 \\
\hline degree of freedom & 15 \\
\hline level of significance & 0.000 \\
\hline
\end{tabular}


According to the results of Friedman test in Table 7, given that the level of significance $(\alpha)$ is less than 0.05 , the claim is not accepted that the ranking of 16 approved strategies are the same; therefore, these strategies have different rankings which are shown in Table 8.

Table 8. Ranking of identified compensation strategies using Friedman Test

\begin{tabular}{|c|c|c|}
\hline Ranking & Strategy & $\begin{array}{l}\text { Rank } \\
\text { Average }\end{array}$ \\
\hline 1 & $\begin{array}{l}\text { Compensation for sales force should be based on } \\
\text { motivating factors in order to enhance the competitive } \\
\text { atmosphere among employees and improve their sales } \\
\text { performance. }\end{array}$ & 7.40 \\
\hline 2 & $\begin{array}{l}\text { Compensation for sales force should be based on both } \\
\text { dimensions of individual efficacy regarding sales and } \\
\text { collective efficacy in the related sales' unit under the } \\
\text { observation of sales management. }\end{array}$ & 7.42 \\
\hline 3 & $\begin{array}{l}\text { Sales force compensation should be in line with both } \\
\text { dimensions of "reaching a company's sales goals" and } \\
\text { "volume of sales". In this regard, sales force } \\
\text { performance must be compensated and rewarded } \\
\text { equally with regard to sales volume increase, sales goals } \\
\text { actualization and market share. }\end{array}$ & 7.44 \\
\hline 4 & $\begin{array}{l}\text { Compensation for salespersons should be based on } \\
\text { establishing and maintaining a good relationship with } \\
\text { customers during sales and the results of such a } \\
\text { relationship for continuity of subsequent sales. }\end{array}$ & 7.78 \\
\hline 5 & $\begin{array}{l}\text { Sales management should perform sales forces } \\
\text { compensation with respect to their performance when } \\
\text { adapting to pre-determined sales plans of the company } \\
\text { as well as their situational performance during } \\
\text { unpredictable cases. }\end{array}$ & 7.90 \\
\hline 6 & $\begin{array}{l}\text { Compensation for salespersons should be considered in } \\
\text { the light of their efforts regarding new or slow selling } \\
\text { products; and a compensation should be considered for } \\
\text { rewarding these additional efforts. }\end{array}$ & 7.95 \\
\hline 7 & $\begin{array}{l}\text { The compensation structure must vary based on sales } \\
\text { force and their positions, and the level of difference } \\
\text { should be based on the difference between sales forces' } \\
\text { relationship with the customers. }\end{array}$ & 8.16 \\
\hline 8 & $\begin{array}{l}\text { Instantaneous wage rates along with sales commissions } \\
\text { must be paid to sales force (e.g. retailers). One must } \\
\text { ensure that a suitable and incentive combination of } \\
\text { salary and sales commission is developed based on } \\
\text { sales conditions for sales force compensation. }\end{array}$ & 8.33 \\
\hline 9 & $\begin{array}{l}\text { In order to compensate sales force who are interested in } \\
\text { challenging tasks and growth opportunities regarding } \\
\text { sales, extra rewards must be paid in addition to base }\end{array}$ & 8.70 \\
\hline
\end{tabular}




\begin{tabular}{|c|c|c|}
\hline & salary. & \\
\hline 10 & $\begin{array}{l}\text { In order to compensate sales force who are interested in } \\
\text { challenging tasks and growth opportunities regarding } \\
\text { sales, extra rewards must be paid in addition to base } \\
\text { salary. }\end{array}$ & 8.74 \\
\hline 11 & $\begin{array}{l}\text { Compensation and rewards for salespersons who } \\
\text { learned new sales patterns and use these methods or } \\
\text { their own innovations to increase sales should be the } \\
\text { same amount as the compensation for those } \\
\text { salespersons who increase the sales volume with the } \\
\text { help of previous and pre-determined practices. }\end{array}$ & 8.88 \\
\hline 12 & $\begin{array}{l}\text { Compensation for sales forces should be established } \\
\text { with respect to their efforts and performance beyond } \\
\text { assigned duties in the sales sector; one should not } \\
\text { merely focus on the results of sales in this regard. } \\
\text { Sales force compensation should not necessarily be } \\
\text { based on their participation in rhetoric, marketing, and } \\
\text { sales techniques seminars, it should rather be based on } \\
\text { the use of these techniques during sales. }\end{array}$ & 8.90 \\
\hline 13 & $\begin{array}{l}\text { Strong non-monetary incentives should be used for } \\
\text { salespersons compensation. Although this method is } \\
\text { difficult to implement, it is suitable when there is a need } \\
\text { to improve other methods of compensation using } \\
\text { additional incentives. }\end{array}$ & 9.07 \\
\hline 14 & $\begin{array}{l}\text { In compensation for salespersons, one must focus on } \\
\text { salespersons' efficiency during difficult selling } \\
\text { situations and attempt to increase their salaries and } \\
\text { rewards. }\end{array}$ & 9.83 \\
\hline 15 & $\begin{array}{l}\text { In compensation for salespersons, employers must focus } \\
\text { on financial incentives alongside with moral incentives } \\
\text { such as the presence of sales managers who listen to } \\
\text { both financial and moral needs of the personnel. }\end{array}$ & 10.54 \\
\hline
\end{tabular}

As shown in Table 8, the first rank among compensation strategies belongs to the statement "Compensation for sales force should be based on motivating factors in order to enhance the competitive atmosphere among employees and improve their sales performance"; and the fifteenth rank belongs to the statement "In compensation for salespersons, employers must focus on financial incentives alongside with moral incentives such as the presence of sales managers who listen to both financial and moral needs of the personnel". In the meantime, the two strategies of "Compensation for sales forces should be established with respect to their efforts and performance beyond assigned duties in the sales sector; one should not merely focus on the results of sales in this regard" and "Sales force compensation should not necessarily be based on their participation in rhetoric, marketing, and sales techniques seminars, it should rather be based on the use of these techniques during sales" jointly shared rank number twelve. The ranking and priority of other strategies are available in Table 8. 
Answering the second research question: What is the status of the study population regarding compensation for services?

In this section, the significance of questions related to the implementation of each compensation strategies in studied companies from the viewpoint of salespersons are examined with comparison of strategies scores using the binomial test. In each of the strategies, two hypotheses named as $\mathrm{H} 0$ and $\mathrm{H} 1$ are assumed. In $\mathrm{H} 0$, a high rate of practicing the mentioned strategy to compensate for sales force and in $\mathrm{H} 1$ a low rate of practicing the mentioned strategy to compensate for sales force in the study companies are intended. If the $\mathrm{H} 0$ is confirmed, there is a high rate of practicing the mentioned strategy to compensate for sales forces in these companies; and if the $\mathrm{H} 1$ is confirmed, there is a low rate of practicing the mentioned strategies to compensate for sales forces in these companies. The test results for the 16 developed strategies are presented in Table 9.

Table 9. Binomial test results to examine rate of practicing compensation strategies for sales force

\begin{tabular}{|c|c|c|c|c|c|c|}
\hline Strategy & & & branch & $\begin{array}{l}\text { observed } \\
\text { ratio }\end{array}$ & $\begin{array}{l}\text { test } \\
\text { ratio }\end{array}$ & sig \\
\hline 1 & $\begin{array}{l}\text { How much does } \\
\text { your company } \\
\text { offer incentive } \\
\text { compensation } \\
\text { (financial and } \\
\text { moral) to } \\
\text { salespersons in } \\
\text { your company? }\end{array}$ & $\begin{array}{l}\text { Low } \\
\text { High } \\
\text { Sum }\end{array}$ & $\begin{array}{l}\leq 3.5 \\
3.5>\end{array}$ & $\begin{array}{l}87 \\
13 \\
100\end{array}$ & 0.50 & 0.000 \\
\hline 2 & $\begin{array}{l}\text { To what extent } \\
\text { is sales force } \\
\text { compensation in } \\
\text { your company } \\
\text { based on both } \\
\text { dimensions of } \\
\text { individual and } \\
\text { group } \\
\text { performance } \\
\text { efficacy in the } \\
\text { related sales } \\
\text { unit? }\end{array}$ & $\begin{array}{l}\text { Low } \\
\text { High } \\
\text { Sum }\end{array}$ & $\begin{array}{l}\leq 3.5 \\
3.5>\end{array}$ & $\begin{array}{l}33 \\
67 \\
100\end{array}$ & 0.50 & 0.060 \\
\hline 3 & $\begin{array}{l}\text { To what extent } \\
\text { is sales force } \\
\text { compensation in } \\
\text { your company } \\
\text { based on both } \\
\text { dimensions of } \\
\text { "reaching } \\
\text { company"s sales } \\
\text { goals" and } \\
\text { "sales volume" } \\
\text { conjointly? }\end{array}$ & $\begin{array}{l}\text { Low } \\
\text { High } \\
\text { Sum }\end{array}$ & $\begin{array}{l}\leq 3.5 \\
3.5>\end{array}$ & $\begin{array}{l}43 \\
57 \\
100\end{array}$ & 0.50 & 0.000 \\
\hline
\end{tabular}




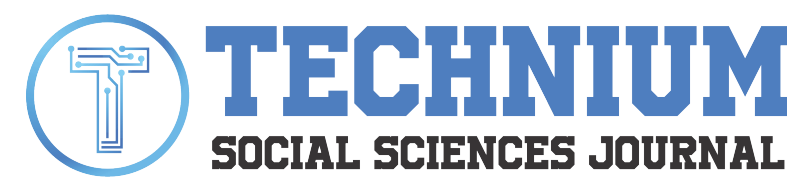

Technium Social Sciences Journal

Vol. 3, 112-140, February 2020

ISSN: 2668-7798

www.techniumscience.com

\begin{tabular}{|c|c|c|c|c|c|c|}
\hline 4 & $\begin{array}{l}\text { To what extent } \\
\text { is 'establishing a } \\
\text { good } \\
\text { relationship with } \\
\text { customers } \\
\text { during sales and } \\
\text { results of such } \\
\text { relationships for } \\
\text { continuity of } \\
\text { subsequent } \\
\text { sales' } \\
\text { considered in } \\
\text { compensation } \\
\text { for sales force? }\end{array}$ & $\begin{array}{l}\text { Low } \\
\text { High } \\
\text { Sum }\end{array}$ & $\begin{array}{l}\leq 3.5 \\
3.5>\end{array}$ & $\begin{array}{l}88 \\
12 \\
100\end{array}$ & 0.50 & 0.080 \\
\hline 5 & $\begin{array}{l}\text { To what extent } \\
\text { does the sales } \\
\text { management pay } \\
\text { attention to } \\
\text { force sales } \\
\text { compensation } \\
\text { with respect to } \\
\text { their } \\
\text { performance in } \\
\text { accordance with } \\
\text { company's } \\
\text { predetermined } \\
\text { sales plans and } \\
\text { their situational } \\
\text { performance } \\
\text { during } \\
\text { unpredictable } \\
\text { cases? }\end{array}$ & $\begin{array}{l}\text { Low } \\
\text { High } \\
\text { Sum }\end{array}$ & $\begin{array}{l}\leq 3.5 \\
3.5>\end{array}$ & $\begin{array}{l}43 \\
58 \\
100\end{array}$ & 0.50 & 0.000 \\
\hline 6 & $\begin{array}{l}\text { To what extent } \\
\text { are additional } \\
\text { rewards offered } \\
\text { to salespersons } \\
\text { for their efforts } \\
\text { to sell new or } \\
\text { slow-selling } \\
\text { products? }\end{array}$ & $\begin{array}{l}\text { Low } \\
\text { High } \\
\text { Sum }\end{array}$ & $\begin{array}{l}\leq 3.5 \\
3.5>\end{array}$ & $\begin{array}{l}54 \\
46 \\
100\end{array}$ & 0.50 & 0.000 \\
\hline 7 & $\begin{array}{l}\text { To what extent } \\
\text { is compensation } \\
\text { structure } \\
\text { focused on } \\
\text { various sales } \\
\text { force positions } \\
\text { and relationships } \\
\text { with the }\end{array}$ & $\begin{array}{l}\text { Low } \\
\text { High } \\
\text { Sum }\end{array}$ & $\begin{array}{l}\leq 3.5 \\
3.5>\end{array}$ & $\begin{array}{l}72 \\
28 \\
100\end{array}$ & 0.50 & 0.060 \\
\hline
\end{tabular}




\begin{tabular}{|c|c|c|c|c|c|c|}
\hline & customers? & & & & & \\
\hline 8 & $\begin{array}{l}\text { What do you } \\
\text { think is the } \\
\text { relationship } \\
\text { between salaries } \\
\text { and } \\
\text { commissions to } \\
\text { compensate } \\
\text { sales force for } \\
\text { their additional } \\
\text { services beyond } \\
\text { assigned duties? }\end{array}$ & $\begin{array}{l}\text { Low } \\
\text { High } \\
\text { Sum }\end{array}$ & $\begin{array}{l}\leq 3.5 \\
3.5>\end{array}$ & $\begin{array}{l}90 \\
10 \\
100\end{array}$ & 0.50 & 0.070 \\
\hline 9 & $\begin{array}{l}\text { Does the } \\
\text { company } \\
\text { consider a } \\
\text { compensation } \\
\text { for those } \\
\text { salespersons } \\
\text { who are looking } \\
\text { for challenging } \\
\text { tasks and growth } \\
\text { opportunities } \\
\text { regarding sales? }\end{array}$ & $\begin{array}{l}\text { Low } \\
\text { High } \\
\text { Sum }\end{array}$ & $\begin{array}{l}\leq 3.5 \\
3.5>\end{array}$ & $\begin{array}{l}47 \\
53 \\
100\end{array}$ & 0.50 & 0.0401 \\
\hline 10 & $\begin{array}{l}\text { Does your } \\
\text { company } \\
\text { consider a } \\
\text { compensation } \\
\text { for salespersons } \\
\text { who learned } \\
\text { new sales } \\
\text { patterns and use } \\
\text { these methods or } \\
\text { their own } \\
\text { innovations } \\
\text { during sales in } \\
\text { order to increase } \\
\text { sales? }\end{array}$ & $\begin{array}{l}\text { Low } \\
\text { High } \\
\text { Sum }\end{array}$ & $\begin{array}{l}\leq 3.5 \\
3.5>\end{array}$ & $\begin{array}{l}52 \\
48 \\
100\end{array}$ & 0.50 & 0.000 \\
\hline 11 & $\begin{array}{l}\text { Does your } \\
\text { company focus } \\
\text { on sales force's } \\
\text { efforts and } \\
\text { performances } \\
\text { beyond assigned } \\
\text { duties when } \\
\text { deciding about } \\
\text { compensation } \\
\text { for sales forces? }\end{array}$ & $\begin{array}{l}\text { Low } \\
\text { High } \\
\text { Sum }\end{array}$ & $\begin{array}{l}\leq 3.5 \\
3.5>\end{array}$ & $\begin{array}{l}43 \\
57 \\
100\end{array}$ & 0.50 & 0.000 \\
\hline 12 & Does $\quad$ your & Low & $\leq 3.5$ & 81 & 0.50 & 0.060 \\
\hline
\end{tabular}




\begin{tabular}{|c|c|c|c|c|c|c|}
\hline & $\begin{array}{l}\text { company } \\
\text { consider a } \\
\text { reward for those } \\
\text { salespersons } \\
\text { who use sales } \\
\text { techniques } \\
\text { during sales? }\end{array}$ & $\begin{array}{l}\text { High } \\
\text { Sum }\end{array}$ & $3.5>$ & $\begin{array}{l}19 \\
100\end{array}$ & & \\
\hline 13 & $\begin{array}{l}\text { Does your } \\
\text { company make } \\
\text { use of strong } \\
\text { non-monetary } \\
\text { incentives in } \\
\text { compensation } \\
\text { for sales force? }\end{array}$ & $\begin{array}{l}\text { Low } \\
\text { High } \\
\text { Sum }\end{array}$ & $\begin{array}{l}\leq 3.5 \\
3.5>\end{array}$ & $\begin{array}{l}95 \\
5 \\
100\end{array}$ & 0.50 & 0.500 \\
\hline 14 & $\begin{array}{l}\text { Does your } \\
\text { company } \\
\text { consider the } \\
\text { efficacy of } \\
\text { salespersons } \\
\text { during difficult } \\
\text { selling situations } \\
\text { in the market } \\
\text { and the } \\
\text { company to } \\
\text { compensate for } \\
\text { sales force? }\end{array}$ & $\begin{array}{l}\text { Low } \\
\text { High } \\
\text { Sum }\end{array}$ & $\begin{array}{l}\leq 3.5 \\
3.5>\end{array}$ & $\begin{array}{l}49 \\
51 \\
100\end{array}$ & 0.50 & 0.000 \\
\hline 15 & $\begin{array}{l}\text { Does } \\
\text { company pay } \\
\text { equal attention } \\
\text { to moral } \\
\text { incentives as } \\
\text { well as financial } \\
\text { incentives in } \\
\text { compensation } \\
\text { for sales force? }\end{array}$ & $\begin{array}{l}\text { Low } \\
\text { High } \\
\text { Sum }\end{array}$ & $\begin{array}{l}\leq 3.5 \\
3.5>\end{array}$ & $\begin{array}{l}64 \\
36 \\
100\end{array}$ & 0.50 & 0.000 \\
\hline 16 & $\begin{array}{l}\text { What is the } \\
\text { amount of } \\
\text { incentive } \\
\text { compensation } \\
\text { (financial and } \\
\text { moral) for } \\
\text { salespersons in } \\
\text { your company? }\end{array}$ & $\begin{array}{l}\text { Low } \\
\text { High } \\
\text { Sum }\end{array}$ & $\begin{array}{l}\leq 3.5 \\
3.5>\end{array}$ & $\begin{array}{l}49 \\
51 \\
100\end{array}$ & 0.50 & 0.000 \\
\hline
\end{tabular}

According to the level of significance obtained from the test, those strategies with a significance level ( $\mathrm{p}$-value) less than 0.05 were endowed with good conditions in the studied companies; so H0 is applicable regarding these strategies $(\mathrm{P}<0.05)$. The strategies that have 
a significance level greater than 0.05 were not endowed with good conditions in the studied companies; so $\mathrm{H} 1$ is applicable regarding these strategies $(\mathrm{P}>0.05)$. Therefore, the strategies that hold a fairly good condition in the studied companies according to which sales force compensation is performed, are as follows:

- There was a fair level of incentive compensation (financial and moral) for sales force in these companies.

- Sales force compensation in these company is focused on both dimensions of "reaching company's sales goals" and "sales volume" conjointly.

- Sales management pays attention to force sales compensation with respect to their performance in accordance with company's predetermined sales plans and their situational performance during unpredictable cases.

- In these companies, additional rewards are offered to salespersons for their efforts to sell new or slow-selling products.

- These company consider a compensation for salespersons who learned new sales patterns and use these methods or their own innovations during sales in order to increase sales (however, comparing the numbers above and below the average value indicates that supporters and opponents of this strategy were almost equal in number and supporters were slightly favored over opponents).

- These companies focus on sales force's efforts and performances beyond assigned duties when deciding about compensation for sales forces (however, comparing the numbers above and below the average value indicates that supporters and opponents of this strategy were almost equal in number and supporters were slightly favored over opponents).

- To some extent, these companies consider the efficacy of salespersons during difficult selling situations in the market and in the company in order to compensate for sales force.

- These companies pay equal attention to moral incentives as well as financial incentives in compensation for sales force (however, comparing the numbers above and below the average value indicates that supporters and opponents of this strategy were almost equal in number and supporters were slightly favored over opponents).

- The amount of incentive compensation (financial and moral) is almost equal for salespersons in these companies.

\section{Conclusion}

Compensation is one of the most important strategies for competition among organizations through human resources in which a systematic strategy design is necessary (Chen \& Peng, 2008). In this regard, the results of current research which was focused on identification of compensation strategies in sales sector indicate that:

Since the sales force and managers of distribution companies in the study believed that the first strategic reference point, i.e. "believing that compensation and rewarding practices in different sectors such as sales sector, communications department, financial department, etc.", must vary to a large extent (average of 4.7 out of 5); therefore, the first compensation strategy in the sales sector of studied companies is as follows:

- The compensation structure must vary based on sales force and their positions, and the level of difference should be based on the difference between sales forces' relationship with the customers.

Since the sales force and managers of distribution companies in the study believed that the second strategic reference point, i.e. "an appropriate mix of base salaries and sales commission for salespersons in accordance with different company conditions (e.g. the startup stages, the intense competitive stage in the market, market downturn stage, etc.)", is a 
good monetary compensation practice; therefore, the second compensation strategy in the sales sector of studied companies is as follows:

- Instantaneous wage rates along with sales commissions must be paid to sales force (e.g. retailers) and one must ensure that a suitable and incentive combination of salary and sales commission is developed for sales force compensation based on sales conditions.

Since the sales force and managers of distribution companies in the study believed that the third strategic reference point, i.e. "the sales volume of a company must be in line with the achievement of company's goals regarding the market (even if the sales volume is not high)", is confirmed with an average level of 3.1 out of 5 ; therefore, the participants believed that one must focus on reaching the goals of a company regarding sales as well as the volume of sales. In other words, the compensation for sales force who increase the volume of sales should be the same as the compensation for sales force who focus on nonfinancial goals of the company in the sales sector. Therefore, the third compensation strategy in the sales sector of studied companies is as follows:

- Sales force compensation should be in line with both dimensions of "reaching a company's sales goals" and "volume of sales". In this regard, sales force performance must be compensated and rewarded equally with regard to sales volume increase, sales goals actualization and market share.

Since the sales force and managers of distribution companies in the study responded to the forth strategic reference point, i.e. "whether the company should consider a link between the efforts of sales force and compensation, or should it only provide base salary and typical rewards?", with a moderately good average (3.9 out of 5); therefore, the forth compensation strategy in the sales sector of studied companies is as follows:

- Compensation for sales forces should be established with respect to sales force's efforts and performance beyond assigned duties in the sales sector and one should not merely focus on the results of sales in this regard.

Since the sales force and managers of distribution companies in the study believed that the fifth strategic reference point, i.e. "is it important to establish a good relationship with customers during sales?", has an average of 3.9 out of 5; therefore, the fifth compensation strategy in the sales sector of studied companies is as follows:

- Compensation for salespersons should be based on establishing and maintaining a good relationship with customers during sales and the results of such a relationship for continuity of subsequent sales.

Since the sales force and managers of distribution companies in the study believed that the sixth strategic reference point, i.e. " the effect of significant financial and moral rewards (such as providing job opportunities for salespersons, monetary and non-monetary prizes, etc.) for sales force compensation on their performance regarding sales volume", deserves a high average of 4.2 out of 5; therefore, the sixth compensation strategy in the sales sector of studied companies is as follows:

- Strong non-monetary incentives should be used for salespersons compensation. Although this method is difficult to implement, it is suitable when there is a need to improve other methods of compensation using additional incentives.

Since the sales force and managers of distribution companies in the study believed that the seventh strategic reference point, i.e. "salespersons who learned new sales patterns and used these patterns or their own innovations during sales in an attempt to increase sales, should receive more pay and benefits in comparison to others", has an average of 3.2 out of 5; hence, salespersons believed that compensation for salespersons who are interested in new sales patterns and innovations regarding sales should be the same amount as the 
compensation for those salespersons who increase the sales volume with the help of oldfashioned and previous practices. Therefore, the seventh compensation strategy in the sales sector of studied companies is as follows:

- Compensation and rewards for salespersons who learned new sales patterns and use these methods or their own innovations to increase sales should be the same amount as the compensation for those salespersons who increase the sales volume with the help of previous and pre-determined practices.

Since the sales force and managers of distribution companies in the study believed that the eighth strategic reference point, i.e. "sales management should perform sales forces compensation with respect to their performance when adapting to pre-determined sales plans of the company", has a low average of 2.1 out of 5 ; thus, these salespersons argued that compensation for sales force should be based on their performance when adapting to predetermined sales plans as well as their situational performance during various sales occasions, in the sense that these salespersons believed that sometimes it is necessary to use situational and contingency approaches in order to increase or manage sales in relation to customers given that these approaches are not included in the pre-determined goals of sales management and distinct compensation and rewards should be offered for these performances. Therefore, the eighth compensation strategy in the sales sector of studied companies is as follows:

- Sales management should perform sales forces compensation with respect to their performance when adapting to pre-determined sales plans of the company as well as their situational performance during unpredictable cases.

Since the sales force and managers of distribution companies in the study believed that the ninth strategic reference point, i.e. "should sales force compensation be based on collective efficacy in terms of their sale unit's efficiency, or individual sales performance is more important?", has an average of 3.1 out of 5; hence, the salespersons stated that both the efficacy of individual sales performance and collective performance in the related sales unit should be considered when making a decision about sales force compensation. Consequently, the ninth compensation strategy in the sales sector of studied companies is as follows:

- Sales force compensation should be based on both the efficacy of their individual sales performance and the efficacy of their collective performance in the related sales unit.

Since the sales force and managers of distribution companies in the study believed that the tenth strategic reference point, i.e. "sales force compensation should be based on motivating factors in order to enhance competitive atmosphere among employees and improve their sales performance", has a high average of 4.1 out of 5; accordingly, the tenth compensation strategy in the sales sector of studied companies is as follows:

- Sales force compensation should be based on motivating factors in order to enhance competitive atmosphere among employees and improve their sales performance

Since the sales force and managers of distribution companies in the study believed that the eleventh strategic reference point, i.e. "sales force compensation should be based on freedom of action for salespersons so that they can sell products in a more creative way and improve their sales performance", has an average of 3.1 out of 5 ; thus, the participants believed that freedom of action during sales and following anticipated goals and dimensions for sales volume management have an equal effect on sales force compensation. This strategic point of view is in line with the conclusions derived from salespersons' comments on the seventh reference point. Therefore, the eleventh compensation strategy in the sales sector of studied companies is as follows: 
- Sales force compensation should be moderately based on freedom of action for salespersons; meanwhile, the role of sales force performance on the basis of pre-determined goals should be considered in compensation decisions.

Since the sales force and managers of distribution companies in the study believed that the twelfth strategic reference point, i.e. "compensation for salespersons should be considered in the light of their efforts to increase the sale volume of new or slow-selling products", has a high average of 4.3 out of 5; thus, the twelfth compensation strategy in the sales sector of studied companies is as follows:

- Compensation for salespersons should be considered in the light of their efforts regarding new or slow selling products; and a compensation should be considered for rewarding these additional efforts.

Since the sales force and managers of distribution companies in the study believed that the thirteenth strategic reference point, i.e. "compensation should be considered for the salespersons who participate in rhetoric, marketing, and sales techniques seminars", has a low average of 2.2 out of 5 . In other words, the salespersons believed that participating in rhetoric and sales techniques seminars cannot affect the performance of salespersons so there is no need to consider a separate compensation or reward for doing so. Therefore, the thirteenth compensation strategy in the sales sector of studied companies is as follows:

- Sales force compensation should not necessarily be based on their participation in rhetoric, marketing, and sales techniques seminars, it should rather be based on the use of these techniques during sales (point of reference and the third strategy)

Since the sales force and managers of distribution companies in the study believed that the fourteenth strategic reference point, i.e. "Compensation is offered to sales force who are interested in challenging tasks and growth opportunities regarding sales and are attempting to do so during sales", has a high average of 4.4 out of 5 ; hence, the fourteenth compensation strategy in the sales sector of studied companies is as follows:

- In order to compensate sales force who are interested in challenging tasks and growth opportunities regarding sales, extra rewards must be paid in addition to base salary.

Since the sales force and managers of distribution companies in the study believed that the fifteenth strategic reference point, i.e. "It is necessary to focus on salespersons' efficiency during difficult selling situations in order to increase their salaries and rewards", has a high average of 4.4 out of 5; therefore, the fifteenth compensation strategy in the sales sector of studied companies is as follows:

- In compensation for salespersons, one must focus on salespersons' efficiency during difficult selling situations and attempt to increase their salaries and rewards.

Since the sales force and managers of distribution companies in the study believed that the sixteenth strategic reference point, i.e. "listening to employees' financial and moral needs (making sure employees understand that the manager cares about their presence in the organization which is essential for the company) can be effective in sale force compensation", has an average of 3.1 out of 5; so the participants were of the opinion that managers who listen to employees' financial and moral needs as a moral incentive can have a moderate effect on their sales performance and compensation, so one should also consider financial incentives at the same time. Hence, the sixteenth compensation strategy in the sales sector of studied companies is as follows:

- In compensation for salespersons, employers must focus on financial incentives alongside with moral incentives such as the presence of sales managers who listen to both financial and moral needs of the personnel

\section{Recommendations}


According to approved strategies with respect to their implementation to a desirable extent regarding compensation in studied companies, it is recommended to sales, marketing, and senior managers of the study companies that:

- Incentive compensation (financial and moral) of sales force in these companies should be performed simultaneously and coordinately. It is possible that sometimes salespersons are in need of moral incentives such as job promotion, improvement of job condition, etc. and this need cannot be met financially or vice versa.

- Sales force compensation in these companies should be according to both dimensions of "reaching a company's sales goals" and "volume of sales". Reaching sales goals such as increasing net profit and improving brand image is as important as sales volume in order for the financial profitability and productivity to promote the performance of organization in the sales sector. This issue should be taken into consideration, especially in various stages of company life cycle.

- Sales management should perform sales forces compensation with respect to their performance when adapting to pre-determined sales plans of the company as well as their situational performance during unpredictable cases. In most cases, salespersons use practical creativities in competitive and contingency situations during sales which is beyond the predetermined frameworks but increases sales volume to a significant degree. Thus, they deserve a reward for doing so while making decisions about compensation.

- In these companies, additional rewards are offered to salespersons who attempt to sell new or slow-selling products of the company. New or off-brand products require more efforts by salespersons to attract customers, achieve customer satisfaction, and increase their purchase intentions. These efforts should be considered in sales force compensation.

- In these companies, rewards are paid in compensate for salespersons who learned new sales patterns and use these methods or their own innovations to increase sales. Salespersons' innovations and creativities during sales and reductions beyond structured and known techniques may affect sales volume.

- In these companies, the sales force is compensated with respect to their efforts beyond assigned duties in the sales sector; these efforts are aimed at achieving customer satisfaction, establishing long-term relationships with them, and improving the image and popularity of company's brand and products which requires additional compensation and rewards in order to be reinforced.

- In these companies, salespersons' efficiency during difficult selling situations in the company and in the market is considered to some extent. Critical conditions such as economic recession, intense competitions in the market, rapid changes in manufacturing technologies, and products quickly becoming outdated all require more efforts by vendors to sell products. Therefore, these efforts should not be compensated only through base salaries and typical rewards, rather, they require additional compensation.

Regarding strategies that do not have a favorable level in the studied companies, it is also recommended that:

- Sales force compensation should be based on both the efficacy of their individual sales performance and the efficacy of their collective performance in the related sales unit. These two dimensions are complementary in terms of sales performance improvement in different parts of an organization.

- In sales force compensation, one must pay attention to salespersons who establish and maintain a good relationship with customers during sales and consider the results of such relationships for continuity of subsequent sales. Establishing a good relationship with the customer is followed by customer loyalty, customer satisfaction, and positive word-of- 
mouth advertising for the company. It also guarantees a safety margin regarding the volume of sales in the future.

- In compensation structure, one must consider various positions of sales force and the level of their relationship with the customers. Salespersons who have direct contact with customers need to make more efforts and demonstrate more energy to satisfy customers.

- In compensation for extra services of sales force beyond the assigned duties, there must be a balance between salary and sales commission.

- More consideration should be given to compensation for sales force who are interested in challenging tasks and growth opportunities during sales and attempt to do so. Considering the financial and moral incentives of these salespersons will increase sales since they implement new sales techniques.

\section{References}

[1] Sturat, Greg L.; Brown, Kent J. (2009), "Human Resource Management", Strategic Relationship, Translated by Seyyed Mohammad Arabi and Marjan Fayyazi, First Edition, Tehran, Mahkameh.

[2] Eskafi, Amir Reza (2005), Organization based on strategic reference points, Master thesis, Faculty of Accountancy and Management, Allameh Tabatabaei University.

[3] Arabi, Seyyed Mohammad (2006), Strategic Management, First Edition, Tehran, Office of Cultural Studies Office.

[4] Arabi, Seyyed Mohammad, Moghadam, Alireza (2007), Coordination of HR Strategies with Business Strategy and Organizational Culture, Journal of Management Science, Vol. 2, No. 8, Pages. 137-103.

[5] Bambergger, Peter; Moshlem, Len (2002), "Human Resources Strategy (Compilation, Performance and Works)", Translated by Dr. Ali Parsaean and Dr. Seyyed Mohammad Arabi, First Printing, Tehran, Office of Cultural Research.

[6] Dehdashti Shahrokh, Zohreh, Pour Hosseini, Amir Hossein (2012). "Presentation of the effect of sales and marketing strategy on the performance of Qurvash". Business Management, Volume 5, Issue 1, 84-61

[7] Redman, Tom, Wilkinson, Adrian (2009), "Advanced Human Resources Management", Translation by Mir Ali Sayed Naghavi, Tehran, Mekhameh Publication.

[8] Bamberger , Peter ; Meshowlem , Lain (2000), "Human Resource Strategy: Formulation , Implementation and Impact ", London: Sage Publication Inc.

[9] Chen, H.M.; Peng , C.F.( 2008), "A systematic framework for performance appraisal and compensation strategy", Human systems management, No.12, 161-177.

[10] Chrzanowski K.R ; Leigh T.W. (1998). "Customer relationship strategy and customerfocused teams". In G. J. Bauer, M. S. Baunchalk, T. N. Ingram, \& R. W. LaForge, Emerging Trends in Sales Thought and Practice (pp. 51-7). Westport, CN: Quorum Books.

[11] Fiegenbaum, A.V; Stuart, A.H; Schendel, D.A (1996), "Strategic reference point theory", Strategic Management Journal, 17: 441-452.

[12] Hall , R.H.(2001), "Organization: Structures" , Processes \& Outcomes , New Jersey : Prentice-Hall.Inc. 8th ed.

[13] Johnston M.W ; Marshall G.W. (2009). "Churchill ford Walker's Sales force Management" ,(9 ed.). Boston: McGraw-Hill.

[14] Keegan W ; Sclegelmilch B. (2001). "Global Marketing Management: a European Perspective".Prentice-Hall. 
[15] Slater S.F ; Narver J.C. (1994). "Does competitive environment moderate the market orientation performance relationship?", Journal of Mark, Vol.58, No.1, 46-55

[16] Spiro R.L ; Rich G.A ; Stanton W.J. (2008)."Management of a Sales Force" ,(12 ed.). New York: McGraw-Hill Irwin

[17] Zoltners, A.A ; Sinha, P ; Lorimer, S. E. (2009). "Building a winning sales force: Powerful strategies for driving high performance", (1 ed.). New York: AMACOM. 